\title{
Physician opinion of the privatization of health care services in Canada: a survey of Canadian urologists by the Canadian Urological Association Socioeconomic Committee
}

\author{
Brian Mayson, MD; ${ }^{*}$ Neil Fleshner, MD, MPH, FRCSC; ${ }^{+}$Alan So, MD, FRCSC; ${ }^{*}$ on behalf of the CUA \\ Socioeconomic Committee
}

\section{Abstract}

Introduction: Canadian health care policy faces unprecedented pressures to reform. With new advances in health care technologies and treatments, proven difficulties in obtaining timely access to necessary health care and the realities of limited fiscal resources sinking in, the status quo is being challenged with the increased role of privately funded health care. To assess the opinions of Canadian urologists on privatization of health care in Canada, the Socioeconomic Committee of the Canadian Urological Association (CUA) surveyed all active members on their beliefs on the role and impact private health care should have in urology.

Methods: We emailed a short survey of 9 questions proposed by the CUA Socioeconomic Committee regarding private health care delivery to all active CUA members in April 2007. We received responses by email, fax or mail over a 1 -month period.

Results: Of the 440 emails sent out, 90 surveys were returned. Respondents believed that a parallel private heath care system would shorten wait times and improve access to care $(74 \%)$, improve outcomes for those with private health care $(58.8 \%)$, would not impair the outcomes of those without private health care $(74.2 \%)$ and would not interfere with the accessibility of health care for most Canadians (73.3\%). Most respondents $(91.1 \%)$ believed that, if privately delivered health care was allowed, urologists should spend a fixed amount of time providing services within the public health care system as well.

Conclusion: This survey on Canadian urologists' beliefs on the role and impact private health care should have in urology indicated that most respondents anticipate a growing influence of private health care and advocate for a regulated fixed proportion of service dedicated to the public system.

Can Urol Assoc J 2009;3(3):193-7

\section{Résumé}

Introduction : Le système de santé canadien subit des pressions de réforme sans précédent. Dans le contexte des nouvelles percées dans le domaine des technologies de la santé et des traitements, des difficultés notoires d'accès en temps opportun aux soins de santé nécessaires et des réalités touchant les ressources financières limitées, le rôle de plus en plus important des soins de santé privés entraîne une remise en question du statu quo. Afin d'évaluer les opinions des urologues canadiens sur la privatisation des soins de santé au Canada, le Comité socio-économique de I'Association des urologues du Canada (AUC) a fait parvenir un sondage à tous les membres actifs concernant leurs perceptions quant au rôle et à l'impact souhaités des soins privés dans le domaine de I'urologie.

Méthodes: Un court sondage comportant 9 questions proposées par le Comité socio-économique de I'AUC sur la prestation de soins de santé privés a été envoyé par voie électronique à tous les membres actifs de l'AUC en avril 2007. Les réponses étaient transmises par courriel, par télécopieur ou par la poste sur une période d'un mois.

Résultats : Sur les 440 sondages envoyés, 90 ont été retournés. La majorité des répondants ont indiqué croire qu'un système de santé privé parallèle réduirait les temps d'attente et améliorerait I'accès aux soins (74\%), améliorerait les résultats pour les personnes bénéficiant d'un tel système privé (58,8\%), mais pas pour les personnes n'en bénéficiant pas (74,2\%), et ne changerait rien à I'accessibilité aux soins pour la majorité des Canadiens et des Canadiennes (73,3\%). La majorité des répondants (91,1\%) croyait que si un système de santé privé était mis sur pied, les urologues devraient tout de même passer une quantité de temps préétablie à prodiguer des soins dans le système de santé public. Conclusion : Ce sondage mené auprès des urologues canadiens concernant leur perception du rôle et de l'impact d'un système de soins privé dans le domaine de l'urologie nous a indiqué que la majorité des répondants semblent anticiper une influence croissante des soins privés et défendre l'idée d'une quantité préétablie et réglementée de temps dédié au système de santé public.

\section{Introduction}

The Canadian health care system appears to be in a state of flux. Recently, there has been considerable discourse among both the public and health policy-makers about the future of the Canadian health care system. The recent precedent-setting June 2005 Canadian Supreme Court ruling in the case of Chaoulli and Zeliotis versus the Attorney 
General of Quebec in which a patient and his physician successfully sued the province after a year-long wait for hipreplacement surgery has further served to galvanize the debate on the role of the private sector in health care. ${ }^{1}$ In this decision, the Supreme Court ruled 4 to 3 to invalidate the long-standing prohibition on private insurance for services that are available under Quebec's public health care plan, stating that it was unconstitutional to deny patients access to private health insurance when the publicly funded system fails to deliver essential services within a reasonable time frame. Health policy-makers in Canada have been forced to re-examine traditional policy based on mounting pressures from increasing surgical wait times and the availability of increasing numbers of private care clinics/ operative centres that continuously expand the variety of available privately funded procedures.

The Canadian Medical Association (CMA) has joined in this debate with its June 2006 discussion paper "It's about access: informing the debate on public and private health care. $^{\prime 2}$ In this publication, the CMA Taskforce on the Public-Private Interface outlines the current status of private involvement in health care delivery and proposes 4 possible scenarios for the future: 1) status quo, 2) medicare plus allowing physicians to opt out of the publicly funded system and allowing paid medical care elsewhere if insured services are not provided in a timely manner, 3) medicare complimented with an expanded safety valve and allowing medically necessary service to be provided both privately and publicly and 4) medicare plus parallel private. This discussion paper seems to support the motion passed at the $2005 \mathrm{CMA}$ annual meeting that "the CMA supports the principle that when timely access to care cannot be provided in the public health care system that patients should have access to private health insurance to reimburse the cost of care obtained in the private sector," allowing a safety valve if the public system fails to provide timely care. ${ }^{3}$ The CMA standpoint for now seems to be privatization if necessary, but not necessarily privatization.

As stated in the CMA release "It's about access," no one group, however well intentioned, can make the decision about the role of the private sector in health care and speak for society as a whole. ${ }^{3}$ All stakeholders must have an opportunity to participate in the debate and be heard. With that in mind, the Canadian Urological Association (CUA) Socioeconomic Committee (SEC) has set forth to survey its members on private health care delivery, with the goal of possibly developing a CUA summary statement representing members' views on what role and impact private health care should have in Canadian urology.

\section{Methods}

We developed a short survey of 9 questions proposed by the CUA SEC on private health care delivery. The survey was available in both English and French, and all SEC members assured the content validity. We emailed the survey to all active CUA members in April 2007, and we resent it in May 2007 to maximize enrolment. We sent out 440 surveys to all actively practising urologists in Canada. We received responses by return email, fax or mail over a 1 -month period. We provided no incentives or rewards to respondents.

\section{Results}

Of the surveys delivered, 90 were returned, 82 in English and 8 in French, for a 20\% response rate. Table 1 presents the composite responses of those questionnaires. Of those surveyed, $56 \%$ performed procedures not reimbursed by the provincial system but paid for by the patient directly. Of those, however, $76.5 \%$ derived less than $5 \%$ of their overall income from nongovernmental reimbursement. Less than $4 \%$ responded that more than $20 \%$ of their overall income was derived from private payment.

When asked to choose 1 of 3 statements that best represented their thoughts on private health care, most respondents $(65.5 \%)$ believed that Canadians should be able to receive, by their own choice, private health care services in Canada. Conversely, $16.7 \%$ of respondents believed that private health care should not be allowed for anything other than "unnecessary" procedures, regardless of wait times.

Respondents believed that a parallel private heath care system would shorten wait times and improve access to care (74\%), improve outcomes for those with private health care $(58.8 \%)$, would not impair the outcomes of those without private health care $(74.2 \%)$ and would not interfere with the accessibility of health care for most Canadians (73.3\%). Furthermore, $73.3 \%$ believed that a parallel private health care system would not reduce the quality of physician care in the public system, whereas $27.7 \%$ believed it would be detrimental to Canadian health care.

Most (86.7\%) Canadian urologists surveyed predicted that Canada would eventually move toward some degree of a parallel private system. When questioned about the role that urologists should play in the private system, $91.1 \%$ felt that they should spend a fixed amount of time providing services within the public system. Of those who felt a fixed amount of time was appropriate, $42.4 \%$ believed that 3 of 5 days per week would be appropriately dedicated to the public system.

When questioned on whether the CUA should issue a 


\section{Table 1. Summary of survey responses}

Question 1

Do you currently perform procedures not reimbursed by your provincial health care

Yes

$56 \%$

No

reimbursement program and paid directly by the patient?

Question 2

If you responded "yes" to question \#1, what proportion of your income would be derived from nongovernmental reimbursement?

$$
<5 \%
$$

5-10\%

$76.5 \%$

$11.8 \%$

$10-20 \%$

$2.0 \%$

$>20 \%$

$3.9 \%$

Unsure

$5.8 \%$

\section{Question 3}

Among the following statements, which one is closest to your opinion regarding private health care? (pick only one)

Canadians should be able to purchase, by his/her own choice, private health care services in Canada.

Access to private insurance/health services should only exist to cover medically necessary services that the public system fails to deliver in a timely manner.

Private health care should not be allowed to pay for medical services regardless of wait times, reversal.

Question 4

Do you think a parallel private health care system will

Shorten wait times and improve access to health care?

Yes

Improve outcomes for those with private health care?

$74 \%$

Impair the outcomes of those without private health care?

$58.8 \%$

Interfere with the accessibility of health care for most Canadians?

$25.8 \%$

Reduce the quality of physician care in the public system?

$26.7 \%$

$26.7 \%$

Be detrimental to Canadian health care?

$27.7 \%$

Question 5

Do you think Canada will eventually move toward some degree of a private parallel

\section{Question 6}

In the event of the establishment of a parallel system, how do you feel urologists should participate in this system?

Spend as much time delivering private care as he/she can

Spend a fixed amount of time providing public health care services

Question 7

If you chose answer (ii) in question 6, what proportion of your time would you see as devoted to the public system?

$20 \%$ (or 1 d per wk)
$40 \%$ (or 2 d per wk)

$60 \%$ (or $3 \mathrm{~d}$ per wk)

$80 \%$ (or 4 d per wk)

Response

$8.9 \%$

$91.1 \%$

Response

$4.7 \%$

$11.7 \%$

$42.4 \%$

$28.2 \%$

Question 8

Do you think that the Canadian Urological Association (CUA) should develop a summary

statement representing the views of Canadian urologists regarding this topic?

\section{Question 9}

Do you think the CUA should promote

Establishment of private health insurance/health care? 
summary statement representing the views of Canadian urologists on privatization in health care, $64.8 \%$ were in favour. In addition, $57.8 \%$ of respondents were in favour of the CUA promoting private health insurance or private health care, whereas $4.5 \%$ were in favour of advocating for disallowance of private health insurance or private health care. Most respondents $(75.3 \%)$ were in favour of the CUA promoting private coverage of certain procedures such as those that have long wait times.

\section{Discussion}

The future of the Canadian health care system and the role that the private sector will play in the funding and delivery of health care is a topic of substantial debate. Opinions appear to be sharply divided across Canada. The Canada Health Act, adopted in 1984, along with provincial and territorial legislation, requires that all medically necessary physician and hospital services be publicly insured with no point-of-service charges for patients. In reality, although predominantly publicly funded, a substantial proportion of health care is privately delivered by physicians and other health care professionals such as pharmacists and physiotherapists outside of public hospitals. ${ }^{3}$ Although there may exist a belief that Canada's health care system is fully funded by the federal and provincial governments, Canada's private share of total health care spending is $30 \%$; this has remained relatively stable since the 1970 s, with about $65 \%$ of Canadians covered by supplemental private insurance, largely driven by the fact that cost of medications are borne privately by most patients., In all provinces excluding Ontario, physicians may opt out of the provincial health insurance plans and charge patients directly for their services, although in practice less than $1 \%$ of Canadian physicians have chosen to do so. ${ }^{2}$ The role of private funding and delivery of health care seems to get further blurred with special populations such as the RCMP, military personnel and those covered under Workers' Compensation.

The future extent of private sector involvement in both the funding and the delivery of health care seems to be unclear. The ideological divide that exists between those who support a fully publicly funded system and those who support an increased role of the private sector are as prominent as ever. Opinions appear to be sharply divided, especially as health care technologies advance at a rapid pace and timely access to necessary health care seems to prove challenging.

When the CMA released its discussion paper "It's about access" in June of 2006 proposing the 4 possible scenarios for the public-private interface, an Ipsos-Reid Poll released in conjunction with the paper demonstrated that of 1000 Canadians randomly polled, $30 \%$ preferred the publicly funded medical care complimented approach, allowing an expanded safety net of services that could be delivered within the private health sphere should the publicly funded system not deliver services within a reasonable time frame and allowing a greater range of essential services to be offered by both the public and private health care systems. ${ }^{5}$ Furthermore, $29 \%$ favoured publicly funded medical care but at the same time advocated for permission to purchase private health insurance to allow care within the private system should it not be provided in a reasonable time frame within the public system. Most importantly, although only $15 \%$ advocated a completely parallel private system, only $26 \%$ of respondents favoured the maintenance of the status quo.

The primary limitation of our study was the low response rate $(20 \%)$. In retrospect, a more aggressive recruitment of active CUA members using fax, regular letter and incentives may have increased the response rate. Furthermore, the opinions of the respondents may not be congruent with those of the CUA membership as a whole, which is a limitation of any survey-based study. However, the results of our study are consistent with those of a similar poll conducted by Ipsos-Reid in July of 2005 that surveyed 200 Canadian physicians on privatization in health care ${ }^{6}$ Physicians were almost evenly split on whether or not Canada needed more privatization in health care, with $53 \%$ supporting privatization of services and $47 \%$ opposing it. Furthermore $88 \%$ of physicians called for a system in which core services were funded by governmental sources, as long as there were guarantees of timely access to services and new resources.

Our survey results demonstrate that within the confines of the current health care structure, there is very little nonpublicly funded urological practice. Just over half of those surveyed currently perform procedures paid directly by the patient; however, this makes up less than $5 \%$ of total revenues for most respondents. When questioned about the role that Canadian urologists feel privatization should play in the future of health care, the respondents echoed the previous Ipsos-Reid polls, suggesting that privatization may eventually play a larger role in the funding and delivery of health care. Most of the urologists surveyed demonstrated a desire for patients to be allowed access to private health care services. However, it seems that the vast majority of urologists in Canada believe this should be closely regulated, with stipulations that physicians must spend a fixed amount of time dedicated to the public system, rather than working completely within the private sphere.

Much of the drive for change within the current health care system seems to stem from frustrations in accessing timely care. As evidenced by the 17 th edition of the Fraser 
Institute analysis of wait times for health care procedures (2007), "Waiting your turn: hospital waiting lists in Canada," accessing Canadian urological services can be a frustrating experience for many patients. ${ }^{4}$ In 2007, the average wait times for referral from a family physician to a urologist was 7.4 weeks, with a further 5.9 weeks from the specialist appointment to treatment, which was up from 5.1 weeks in 2006. Not surprisingly, most of the Canadian urologists polled see an expanding role for the private delivery of health care as one way of shortening wait times and improving access to care while not impairing the outcomes of those within the public system.

\section{Conclusion}

With new advances in health care technologies and treatments, proven difficulties in obtaining timely access to necessary health care and the realities of limited fiscal resources sinking in, the status quo is being challenged with the increased role of privately funded health care. Hence, there is an apparent growing concern among the general public and physicians that the status quo may be insufficient. Our survey of Canadian urologists on their beliefs on what role and impact private health care should have in urology indicated that most respondents seem to anticipate a growing influence of private health care and advocate for a regulated fixed proportion of service dedicated to the public system.
From the *Department of Urologic Sciences, University of British Columbia, Vancouver, BC and the †Divison of Urology, Department of Surgery, University of Toronto, Toronto, Ont.

Acknowledgements: The members of the CUA SEC: Neil Fleshner (chair), Lorne Aaron, Scott Bagnell, Jack Barkin, Darryl Drachenberg, Greg Kozak and Alan So.

This article has been peer reviewed.

Competing interests: None declared.

\section{References}

1. Chaoulli v. Quebec (2005), 1 S.C.R. 791, 2005 SCC 35. Available: www.canlii.org/en/ca/scc/doc /2005/2005scc35/2005scc35.html (accessed 2009 Apr 20).

2. Canadian Medical Association. Task force on the private-public partnership. It's about access! Informing the debate on public and private health care: discussion paper. Ottawa: The Association; 2006. Available: www.cma.ca/index.cfm/ci_id/48620/la_id/1.htm (accessed 2009 Apr 20).

3. Sullivan P. Privatization if necessary, not necessarily privatization. Ottawa : Canadian Medical Association; 2005. Available: www.cma.ca/index.cfm?ci_id=10028034\&la_id=1 (accessed 2009 Apr 20).

4. Esmail N, Walker M. Waiting your turn: hospital waiting lists in Canada 17th ed. Vancouver: the Fraser Institute; 2007. Available: www.fraserinstitute.org/researchandpublications/publications/4962.aspx (accessed 2009 Apr 20).

5. Kondro W, Sibbald B. CMA proposed option for private-public split. CMAJ 2006;175:18-20.

6. Sullivan P. CMA polls show some optimism following Supreme Court ruling. Ottawa: Canadian Medical Association; 2005. Available: www.cma.ca/index.fm?ci_id=10027778\&la_id=1\&print=true (accessed 2009 Apr 20).

Correspondence: Dr. Alan So, The Prostate Centre, Department of Urologic Sciences, Vancouver General Hospital, 2660 0ak St., Vancouver BC V6H 376; fax 604 875-5654; dralanso@interchange.ubc.ca 